\title{
Sugut greenschist complex of southern Tien Shan, Kyrgyzstan: Tectonic structure and metamorphism
}

The Paleozoic Sugut greenschist complex is situated within the limits of the Variscan-age Tien Shan of the State of Kyrgyzstan. The complex contains greenschists formed in basalts and their tuffs, as well as aleurolites, argillites, and sandstones. This region has not been investigated in detail previously, and this study has determined the geologic structures, tectonic structures, and character of metamorphic distribution.

Detailed structural mapping, which includes tectonic-facies analyses, has provided an opportunity to study the lack of uniformity in the degree of deformation of the rocks. The complex formed under dynamic metamorphic flow in ductile fault zones during the formation of the regional structures of Variscan age.

\section{Introduction}

Greenschist complexes are spread worldwide, and they form broad zones in North America, Australia, New Zealand, Japan, Europe, and Asia. Geologists in many specialties have been studying these zones over the past 30 years.

Variously named complexes metamorphosed to the greenschist facies are distinguished in the region of Variscan-age folding in southern Tien Shan (spelled Tyan'-Shan' locally) in the State of Kyrgyzstan. These complexes are found in Kyzyl Kum, the Zeravshan-Gissar region, northeastern Fergana, the Alai Ridge, the Dzhangdzhir range, the At-Bashy-Too mountains, and the eastern Alai Ridge.

This paper is devoted to the Sugut greenschist complex, which is located on the eastern Alai Ridge in the southern Tien Shan (fig. 1). The district here has a complicated structure and is found in the axial zone of the Terekdavan synclinorium, which contains deposits of middle Paleozoic age. The Sugut complex has the upper position in a series of regional nappes (fig. 2). The paraschist and orthoschist series that developed here are heavily deformed and underwent metamorphism to the greenschist facies.

Until the 1980s, the Sugut complex was considered to be a Precambrian massif that had not been deformed during the time of Variscan tectonic movement. In fact, until now, geologists have not known much about the Sugut's geologic structure, age, and type of metamorphism. Furthermore, the extensive deformation of the rocks
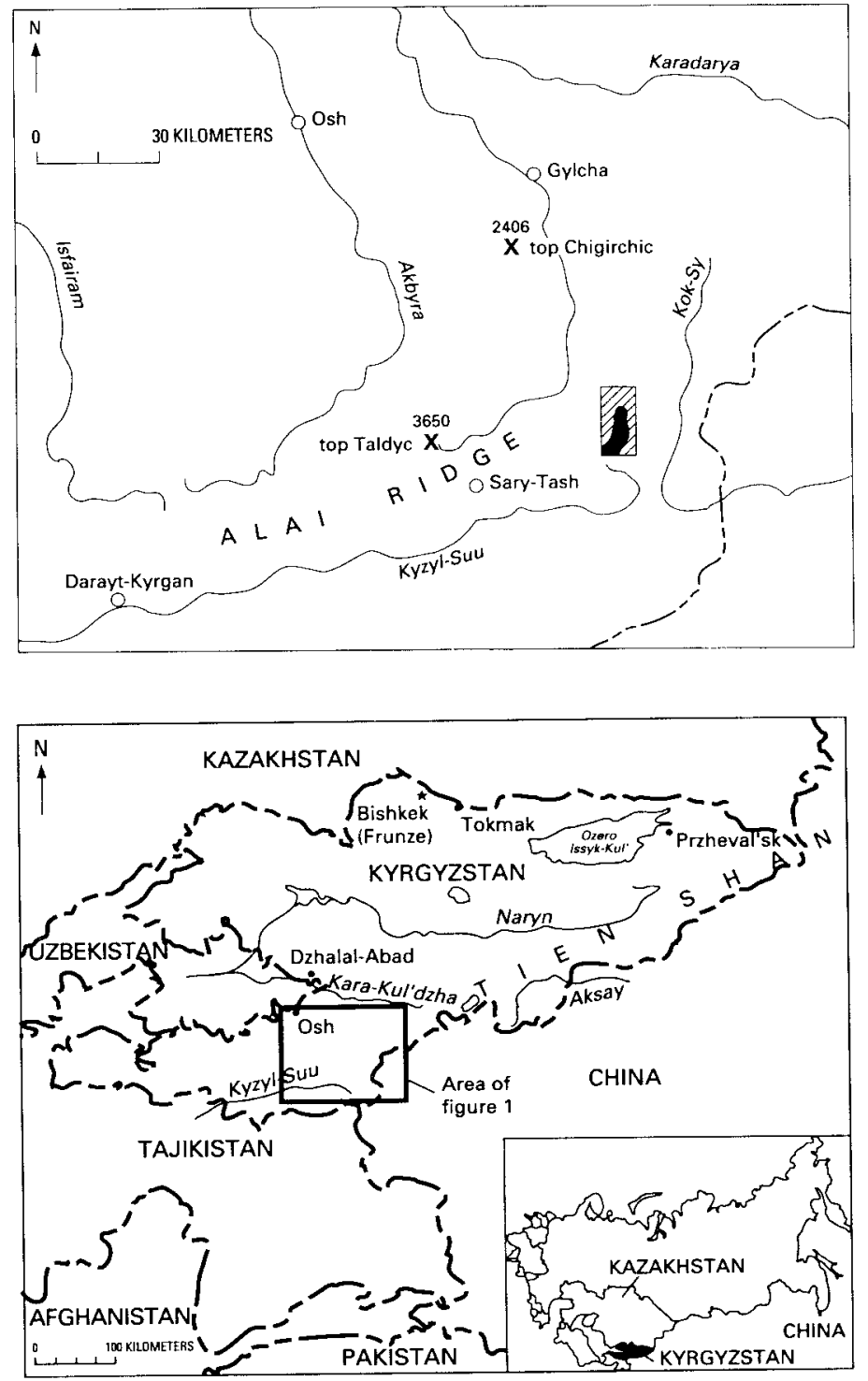

Figure 1.-Map of investigated region in southern Kyrgyzstan. Patterned area shows location of mapped area. Altitudes are given in meters for Taldyc and Chigirchic passes.

gives us no opportunity to determine the Sugut's primary bedding. Because fossils are seldom seen and normally are absent, the age of the deposit cannot be determined. 


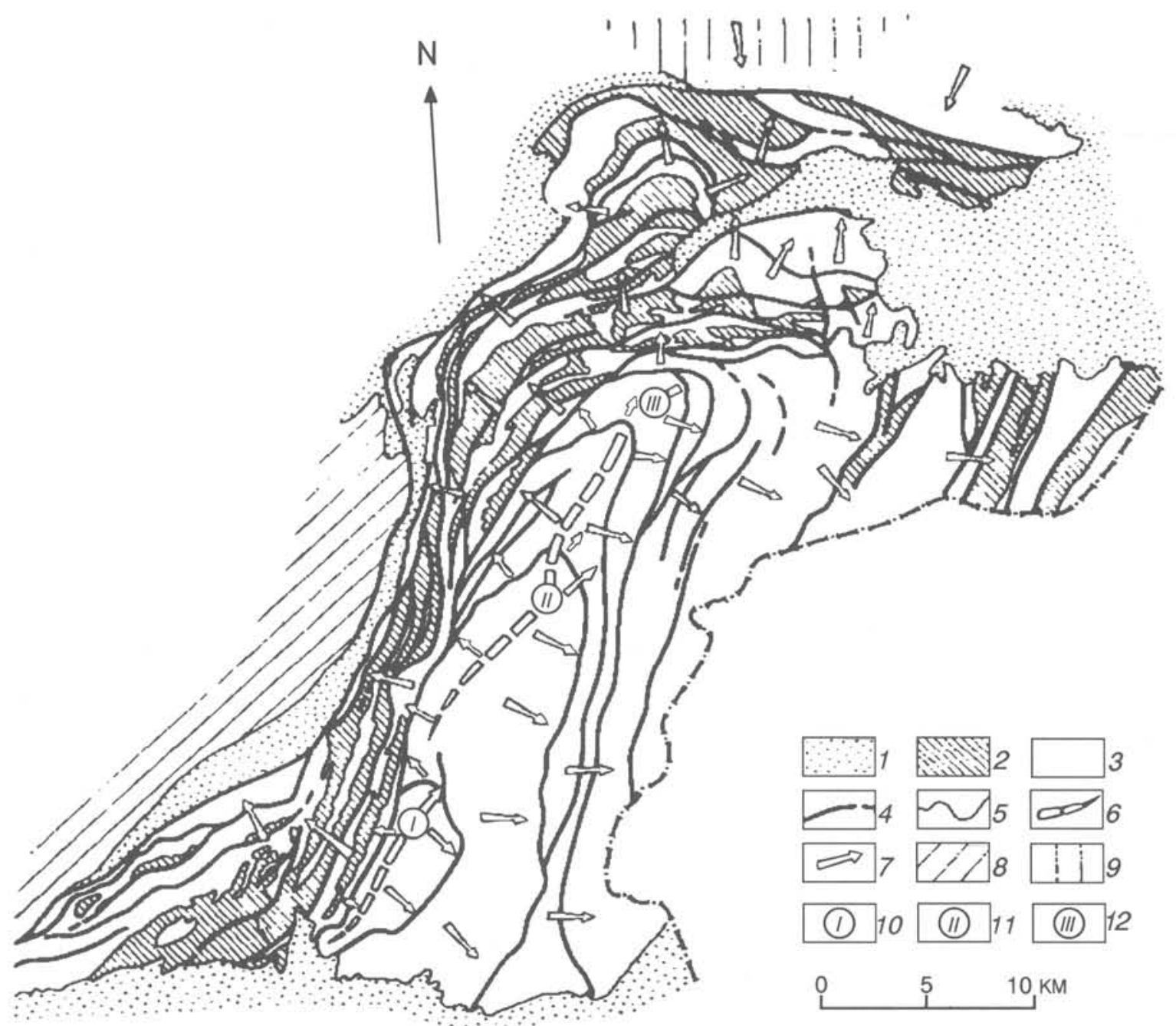

Figure 2.-Tectonic scheme of eastern Alai Ridge. Explanation: 1, Mesozoic and Cenozoic rocks; 2, upper Paleozoic rocks; 3 , middle Paleozoic rocks; 4 , existing and inferred faults; 5 , stratigraphic contact; 6 , syncline of the eastern Alai axial zone; 7, direction of mass movement; 8, Gulchin zone; 9, Yassin zone; regional nappes: 10, Sugut-Kokkiya; 11, Bleulin; 12, Dombrin. (Drawn according to data of A.V. Yagovkin, V.L. Klishyavich, V.D. Brezhnev, and A.E. Dovzhikov, 1977.)

The work described here is important for deciphering the tectonic structure of the Sugut greenschist complex. Detailed mapping of the basement rocks was conducted at a large scale of $1: 25,000$ by using the tectonic-facies method (Patalakha, 1985). The use of this effective method permits one to show the distribution character of the unequally metamorphosed rocks, to determine the degrees of deformation of the rocks according to a 10-point scale, and to divide the complex into units showing different degrees of deformation.

\section{Investigation of history of geologic structure}

The first papers that mention the Sugut complex are papers by D.P. Rezvoy. He suggested that the Sugut complex be referred to the terrigenous Terekdavan type section, and he considered its age to be Precambrian (Rezvoy, 1959; Rezvoy and others, 1983). Porshnyakov
(1973) did not distinguish between the metamorphosed schists and the nonmetamorphosed rocks included in the Terekdavan type section. Burtman (1976) considered the metamorphic schists in the upper part of the Variscan leptogeosynclinal deposits to be of a volcanic-terrigenous type. Yagovkin (1974) determined that the metamorphic schists were Precambrian formations and that the nonconforming, higher, bedded Suuktor suite was Paleozoic in age. Dovzhikov (1977) more precisely resolved the age, composition, and structural location of the Sugut schist. Shvanov (1983) followed and divided the Sugut series into three units: the volcanic, siliceous, and terrigenous-carbonate units. Although Rezvoy (1959) considered the structure to be anticlinal, Dovzhikov (1977) named it the SugutKokkiya syncline. Yagovkin (1974) determined that the metamorphism was regional in scope, but Shvanov (1983) considered the metamorphism to be local, and he pointed out the gradual change from nonmetamorphosed to metamorphosed rocks. It is difficult to determine a pattern in the distribution of metamorphism, but one can observe the strengthening of metamorphism along the faults and 
crumple zones. Shvanov (1983) recognized the metamorphism as a dynamic stress, epigenic type of regional metamorphism.

Before trying to find the sense of the tectonic structure, we should look at the geologic section that resulted from the investigations reported herein. All the units of the section are represented in the central part of the Sugut metamorphic complex (fig. 3). At the base of the section lies a siliceous-terrigenous unit having a thickness of as much as $250 \mathrm{~m}$. Structurally - and maybe stratigraphically higher lies a unit of volcanic rocks that have been transformed into orthoschists, as well as layers of metasandstones, as much as $1 \mathrm{~km}$ thick. The contact between the volcanic rocks and the underlying siliceous-terrigenous unit is in conformity. A unit containing aleurolites, argillites, sandstones, and clay schists completes the section. Parts of the upper unit contain layers and lenses of reef limestones that have been weakly marbleized. The thickness of the upper unit ranges from $100 \mathrm{~m}$ to $700 \mathrm{~m}$, and only the upper unit is characterized by fossils. Its marbleized limestones contain fossils in the form of heavily crystallized crinoids. These fossils mark the age of the upper unit as an interval from the Late Silurian to the Early Devonian.

\section{Tectonic structure and tectonofacies analyses}

The Sugut greenschist complex has a synformal structure that is expressed clearly in its central part and in the north of the structure in the centroclinal shortening area (fig. 3 ). The structure is heavily compressed in the southwest, where it is converted into a monocline that falls in a northwestern direction. The metamorphic strip is overlain by terrigenous rocks of the Terekdavan type section, which is represented by aleurolites, argillites, and sandstones. These units are crumpled into a fold system that has northwesterly oriented axial planes. The Sugut complex corresponds to a mesozone having unevenly distributed deformation intensities. Rocks are destroyed by ductile faults that divide the territory into longitudinally lensing, lamellar blocks striking chiefly northeast. On the grounds of the predominant layering elements. deep faulting, and commonly slaty fold cleavage, one can distinguish zones that are deformed in the tectonofacies interval from intensity III to intensity X (fig. 4). Ductile faults, slaty cleavage, and folds form the main structural triad, and all of these elements are parallel.

In addition, the author has mapped single faults, zones of slaty flow, and zones of boudinage that include various types of structures. These features gave me the opportunity to do tectonofacies mapping by distinguishing separate districts that have different degrees of deformation. The mesozone features include cleavage, veins of alpine type, boudinage, ptygmas, linearity, and folds showing ductile flow. The structures and textures of the rocks in thin sections add to the information gained from mapping the Sugut tectonofacies in the field. Where some of this information is sketchy, one can only guess about its existence on the grounds of fragmentary observations.

Tectonofacies analyses of the Sugut greenschist complex show that the area is not uniformly deformed (fig. 4) according to the development of ductile flow, but this ductile flow covers all sections of the metamorphic strip. Some sections have a degree of deformation that increases locally and corresponds to a katazone, in contrast to the mesozone background. In the areas of katazone development, the primary bedding is lost completely, and these sections commonly appear to be higher in the structure than the sections showing mesozone development, in spite of the commonly uninterrupted geologic section. This relationship testifies to the complicated and contrasting ductile flow that is found on different levels of the Sugut complex.

\section{Metamorphism and deformation of the Sugut complex}

$\mathrm{O}_{\mathrm{n}}$ the basis of the metamorphic features of the Sugut rocks, we can say that the greenschist resulted from dynamic metamorphism of the Silurian to Devonian volcanic and terrigenous deposits. The metamorphism shows the presence of stress and is concentrated in zones of rock that have greater deformation intensity. The degree of rock deformation ranges from metagenesis to different subfacies of greenschist metamorphism. Studying the degree of deformation of the Sugut complex in the sections and in the vicinity permitted me to establish the irregular distribution of metamorphic rocks. The lack of uniformity was revealed and mapped both at the level of the overall lithostratigraphic subdivisions making up the greenschist complex and at the level of every separate rock unit.

Overall, the siliceous-terrigenous unit has undergone metagenesis, the volcanic rocks have been metamorphosed to greenschist, and the overlying terrigenous unit has undergone metagenesis and, in its upper part, greenschist metamorphism. The transitions are gradual from the metagenetically changed rocks to the greenschists, and the limits of the zones that are marked according to the degree of deformation coincide with the metamorphic zones. Let us examine the relationship of the degree of deformation and the transformation of the components of the Sugut series within the limits of the separate structure in the northern part of the complex (fig. 5). The siliceousterrigenous unit and the volcanic unit of the section crop out in this district. Detailed structural mapping of the Sugut complex has revealed its complicated structure in the area between the Sugut and Tepshi rivers and has refined the earlier ideas on the lack of uniformity of deformation and development of metamorphism within the Sugut series rocks (Soloviev, 1986, 1987).

The Sugut section in the mapped area is composed of the siliceous-terrigenous unit that gradually transforms into volcanic rocks going upward in the section. The zone of transformation is a unit of sand tuff, the tuff's consisting of basaltic porphyrite, and it has a thickness of as much as $60 \mathrm{~m}$. The thickness of the siliceousterrigenous unit ranges from 400 to $600 \mathrm{~m}$, and the volcanic series, from 600 to $800 \mathrm{~m}$.

The northern limit of the siliceous-terrigenous unit is tectonic in nature and is represented by a 20 -m-thick zone of limestones that have a schistose structure and that transform into massive limestones (Devonian to Carboniferous). One can see the limestones fall in the southwestern direction at an angle of $60^{\circ}$ under the siliceousterrigenous unit. The upthrust Tashuy northern fault serves as the eastern limit of the siliceous-terrigenous and volcanic units. Terrigenous rocks of the Terekdavan type section, which have no signs of metasomatism, are situated beyond the Tashuy fault. Units of sandstones, aleurolites, and argillites are cut obliquely by the Tashuy fault and come close to the metamorphic schists of the Sugut series. Along the fault zone, dikes of granite porphyry of Permian age are present.

Siliceous and volcanic rocks of the Sugut complex between the Sugut and Tepshi rivers form a synclinal fold that has limbs dipping from $40^{\circ}$ to $80^{\circ}$. A synclinal fold of the second order is mapped inside the volcanic series. It is composed of different albiteactinolite-chlorite orthoschists that alternate with albite-chloritesericite schists. The limbs of this second-order fold dip $40^{\circ}$ to $50^{\circ}$. Two folds that have limbs dipping $60^{\circ}$ are mapped in the terrigenous series in the southeastern part of the mapped area and are in tectonic contact with the volcanic series. They are revealed by layers of quartz-chlorite-albite-muscovite schists formed in sandstones. Many schistose zones and mylonitic zones that are cut by quartz veins are found at the edges of the rock units. Some horizons are deformed into a system of folds that are characterized by different thicknesses of layers on the crests and limbs of the folds. 


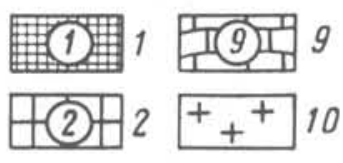

|ख्या $2 a$ C- 11

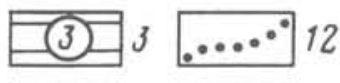

(4) 4 - 13

(5) 5 T- 14
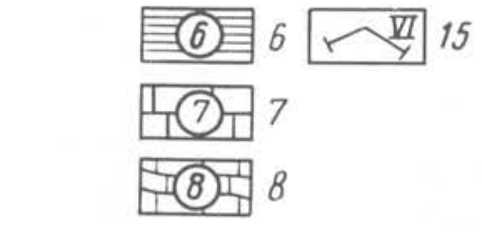


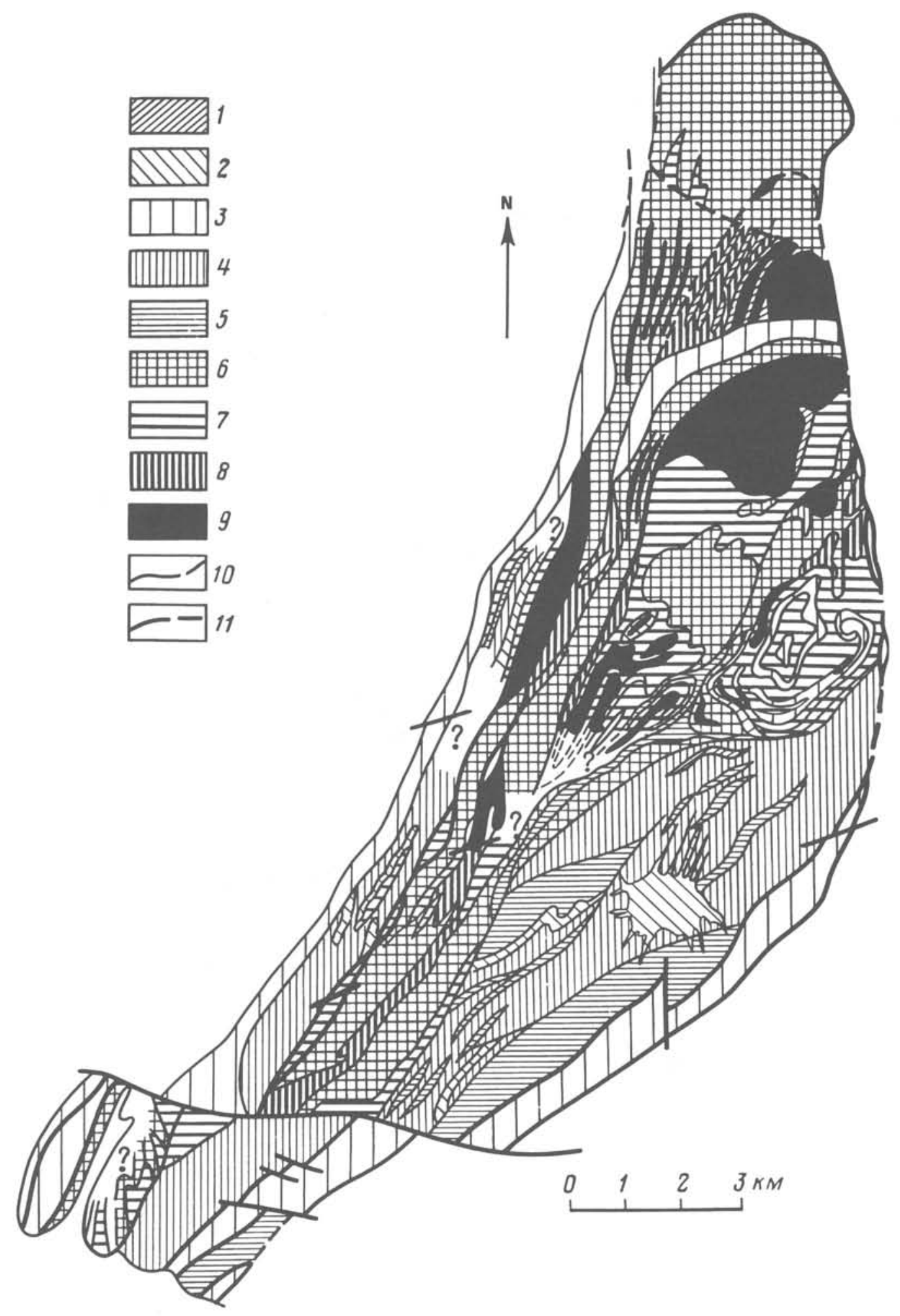

Figure 4.-Tectonofacies map of the Sugut complex. Explanation: 1-9, tectonofacies intensity (1, III; $2, I V ; 3, V-V I I$ (in general); 4, V; 5, VI; 6, VII; 7, VIII; 8,IX; 9, X); 10, existing and inferred tectonofacies limits; 11 , existing and inferred faults. Queried where unknown. 


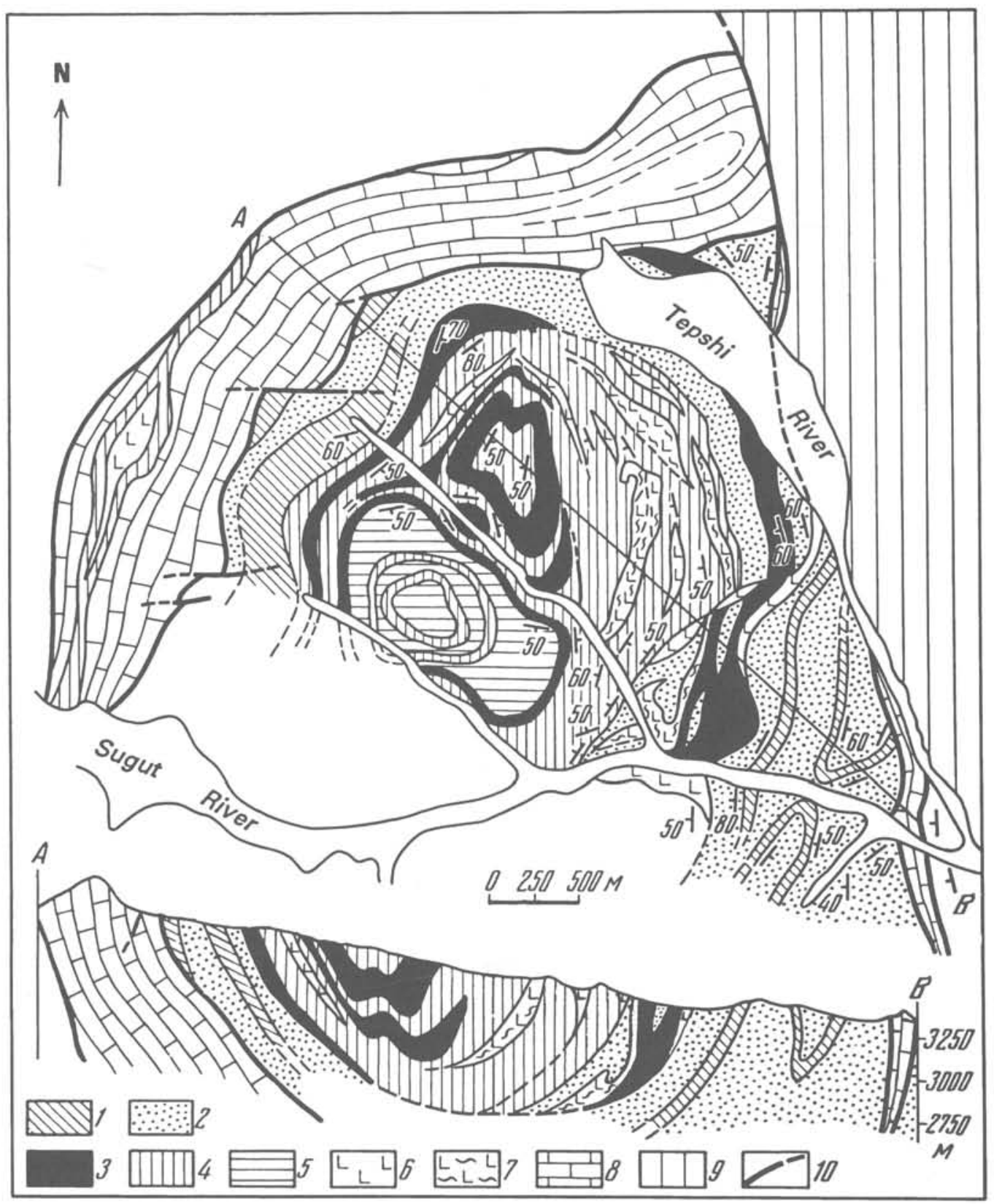

Figure 5.-Metamorphic map of the northern part of the Sugut greenschist complex (see fig. 3 for location) in the area between the Sugut and Tepshi rivers. Explanation: 1-7, Sugut series (SilurianDevonian); 1, 2, siliceousterrigenous rocks; $(1$, flint and paraschists of quartz-clay-hydromicaceous subfacies; 2, paraschists of quartz-chlorite-albitemuscovite subfacies); $3-7$, volcanic rocks; (3, orthoschists of albiteactinolite-chlorite subfacies; 4 , orthoschists of albite-chlorite-sericite subfacies; 5 , metamorphosed basalt and tuff of basaltic porphyrites; 6 , diabase and basaltic porphyrites; 7 , talc-carbonate-chlorite schists); 8, limestones (DevonianCarboniferous); 9, nonmetamorphosed rocks of Terekdavan section type; 10, existing and inferred faults. Bedding dips are shown as well.
The various lithological groups of rocks that have been metamorphosed to different degrees show lensing or a striped design. Regarding the relationships among the groups of rocks, one can see that clay schists and clay-chlorite, weakly sericitic schists are replaced along strike by quartz-chlorite-albite-muscovite schists. The replacement takes place gradually going to the northeast. A substantial transformation in the appearance of muscovite is revealed by an increase in the degree of deformation, which also is expressed by the strengthening of the schistosity of lamellar microlithons (the thickness going from $2-3 \mathrm{~mm}$ to $1 \mathrm{~mm}$ or less) and by the loss of folds that are subparallel to the bedding during the formation of lineation. Newly formed minerals of albite and muscovite are found on the schistose planes, and zones of intergrain stretching are expanded gradually, as is illustrated in thin sections. The rock acquires the texture of crystallized schistosity. It is composed of a fine-grained albite aggregate and has scales of chlorite, sericite, and muscovite that show granoblastic to lepidoblastic texture, which is a schistose texture shown by parallel scales of sericite and muscovite. Substantial differentiation appears in places as a process of division into thin stripes of micaceous and albitic material. Subparallel quartz veins are separated by micaceous material and form boudinage structures. One can map the uneven development of deformation in relict bodies of basaltic and diabasic porphyrites. Not even the inner structures of these bodies show a zonal picture of the brecciation zones or of the schistose microlithons having different morphologies and thicknesses.

The higher the degree of perfection of the microlithons, the more new formations appear. The rock is represented in zones of maximal flow by albite-chlorite-epidote-actinolite-striped schists, which reveal substantial differentiation in the form of light and dark 
layers having clear borders. These rocks are characterized by lepidoblastic and granoblastic structures. All the rock mass is transformed, including the relict grains of augite.

In the upper reaches of the northern tributary of the Sugut river, green-to lilac-colored albite-actinolite-chlorite schists are replaced in a southwestern direction along the strike by albite-chlorite-epidotebiotite schists that have granoblastic to lepidoblastic structures. They are composed of fine-grained, nearly cryptocrystalline albite and quartz, as well as small scales (up to $0.4 \mathrm{~mm}$ long) of chlorite and biotite. The appearance of biotite is typical of a higher degree of transformation and is followed by structural changes in texture, such as a more regular microtexture and small-scale folding that is transformed into typical flow folds on the microlevel. The limbs of the folds are truncated by microfolds, and the morphology of the microfolds reveals the presence of ductile flow. The layers on the limbs become thinner and gradually transform in the fault plane, which is a schistose zone that has microlithons as thick as $0.5 \mathrm{~mm}$. The texture of the rock becomes striped with lenses, and striped areas of abnormally high transformation in structure and texture are mapped in the eastern part of the region in the terrigenous rocks northeast of the confluence of the Sugut and Tepshi rivers.

The degree of rock deformation is determined by a number of factors including the lithological features of the rocks, the character of the rock units and discontinuous layers, and their composition and thickness. At the same time, the ductile flow in the Sugut metamorphic complex played the leading role in substantially transforming the texture of the rocks. The relatively low thermal conditions and the kinetic features of the dynamic metamorphism and ductile flow determined the incomplete mineral reactions and the instability of mineral formation. Therefore, one can map in the study area the limits of the different stages of substantial transformation, the striped locations of lenses, and the absence of metamorphic zones.

The process of ductile flow in the rocks of the Sugut metamorphic complex is shown in following ways: (1) Synkinematic recrystallization, where the grain number and dimensions grow as the degree of deformation increases from middle (levels VI-VII) to higher (VIII-X) tectonofacies intensity; (2) stretched intergrains in quartz aggregates in schists formed in basaltic porphyrites and their tuffs and in calcite aggregates in terrigenous rocks; (3) polygonization division of large grains into smaller grains that have mosaic structures, as is typical of quartz aggregates; and finally, (4) the flow of rocks that were formed as a result of fragmentation by a system of ductile-flow zones of different intensities.

Analyses of the degree of transformation within the investigated area allowed me to map two levels of transformation according to two mineral subfacies each: in the metapelites, the quartz-clayhydromicaceous subfacies and the quartz-chlorite-albite-muscovite subfacies, and in the metabasalts, the albite-chlorite-sericite subfacies that has relict augite and hornblende and the albite-actinolitechlorite subfacies. The metamorphic complex does not reveal metamorphic zones, but it is characterized by a lack of uniformity, which is expressed by the appearance of rocks having different degrees of metamorphism in the section.

Carrying out detailed tectonofacies analyses on the mapped area permitted me to determine the irregular deformation on the mesozone level. This level shows two degrees of deformation in the area between the Sugut and Tepshi rivers. They correspond to the middle and high tectonofacies, and they reflect different intensities of the dynamic-metamorphism and ductile-flow process (fig. 6).

The middle tectonofacies (intensity VI-VII) are characterized by the following elements: folds in the subparallel flows, lenses of microlithons in the rock $(0.5-0.7 \mathrm{~cm}$ thick), boudinage of the subparallel quartz veins, and various examples of crenulation cleavage and kinkbands. The higher tectonofacies (VIII-X) are characterized by an increasing degree of schistosity going from lamellar microlithons (as much as $0.2 \mathrm{~cm}$ thick) right up to mylonite, which is shown by mineral linearity and a striped appearance in schists that, in places, have secondary subparallel folds. The striping is crumpled in these folds.

Analyzing the deformation characteristics of rocks of various compositions that affect ductile flow, the author determined the following types of rock stability: Tuffs of basaltic porphyrites and basaltic porphyrites themselves react first upon deformation. Terrigenous rocks having a high content of volcanic material mixed in react and become albite-actinolite-chlorite rocks. In zones of intense deformation (VIII-X intensity facies), they transform into albitechlorite-epidote-actinolite schists containing biotite and hornblende and have a texture that is striped with lenses, which reveal a clear differentiation of the components. Third in the deformation series are the aleurolites and sandstones, and they transform into quartzchlorite-albite-muscovite schists that have the textural features of dynamoschists.

The exposed material shows that the relative increase in the transformation of the components took place in zones having high tectonofacies classifications. These zones appear at different levels of the Sugut metamorphic complex and point to a paragenetic connection between metamorphism and the ductile flow of the material.

\section{Conclusions}

As follows from the above discussion, the arched bend of all contacts is typical of the Sugut complex. This bend is emphasized by the limestone ridge that frames the greenschist complex. Its rocks have undergone intensive ductile deformation, which is expressed by boudinage structures, schistosity, mylonitization, and flow folds. Because the deformation is not evenly distributed, some horizons slip with respect to others on planes where the degree of deformation meets the higher classifications of tectonofacies.

Structural drawings of the Sugut complex testify to the process of ductile flow's taking place along the lines of the common structural strike, that is, from the south to the north. Supercharging of the material is determined from the presence of diametrical folding at tectonic scales in the area of the centroclinal bend in the north of the structure. The ductile-flow process caused stratification of the originally uniform section and formed a complex overthrust structure, nappes, and flow zones of different intensities in the material. Ductile faults (high tectonofacies zones) form the planes of complex stratification and overthrust structures.

The Sugut complex is characterized by the irregular distribution of metamorphism. Metamorphic zones are subdued in relation to the structural zones, as is shown by the mapped limits of metamorphism (fig. 5) and tectonofacies (fig. 6). Dynamic metamorphic flow in the ductile fault zones is the main reason for combined greenschist-facies metamorphism and intensive deformation in these zones. The ductile flow caused stratification and overthrusting. The modern distribution of metamorphism and deformation in the axial zone of the eastern Alai Ridge was formed under this influence as well.

\section{References}

Burtman, V.S., 1976, Structural evolution of Paleozoic fold systems: Moscow, Nauka Publishers, 289 p. [In Russian.]

Dovzhikov, A.E., 1977, South Tien Shan tectonics: Moscow, Nedra Publishers, 170 p. [In Russian.]

Patalakha, E.I., 1985, Tectonofacies analyses of folding, Phanerozoic architecture (grounds, methods, supplement): Moscow, Nauka Publishers, 201 p. [In Russian.] 


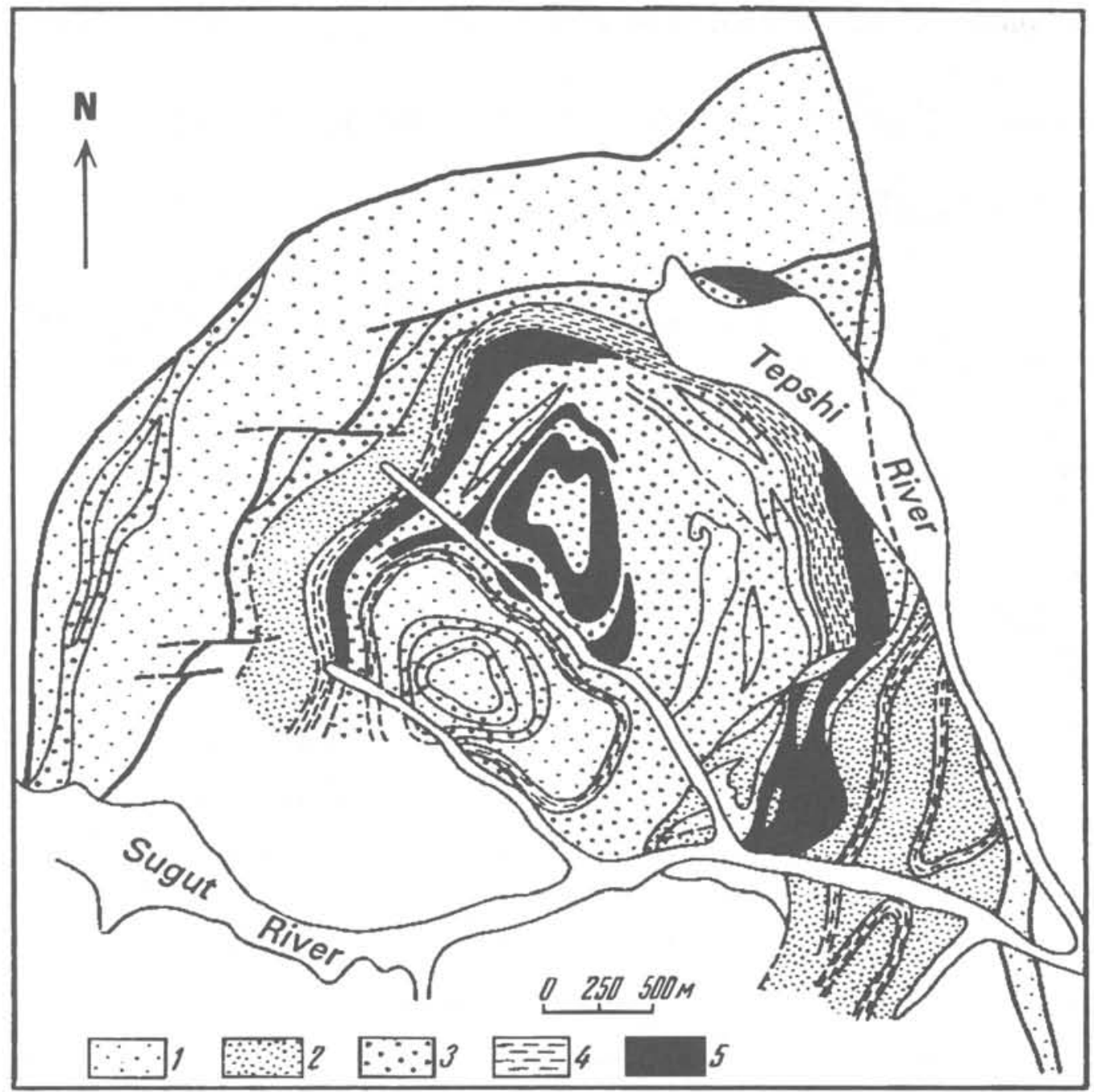

Figure 6. -Tectonofacies map of the Sugut greenschist complex in the area between the Sugut and Tepshi rivers. Tectonofacies intensity: $1, V I ; 2, V I I ; 3, V I I I ; 4, I X-X ; 5, X$.

Porshnyakov, G.S., 1973, Hercynides of Alai and adjoining regions of Tien Shan: Leningrad, Leningrad State University Publishers, 216 p. [In Russian.]

Rezvoy, D.P., 1959, Tectonics of Turkestan-Alai mountain system, eastern part-some aspects of South Tien Shan geology: Lvov, Lvov State University Publishers, v. 1, 372 p. [In Russian.]

Rezvoy, D.P., Alekseyenko, A.V., Marushkin, I.A., and others, 1983 Concentric structures-new in the southern Tien Shan tectonics-tectonics of Tien Shan and Pamir: Moscow, Nauka Publishers, p. 73-78. [In Russian.]

Shvanov, V.N., 1983, Lithofacies correlation of terrigenous and metamorphic beds in the southern Tien Shan: Leningrad, Leningrad State University Publishers, 220 p. [In Russian.]

Soloviev, A.Yu., 1986, Geological structure and tectonofacies of eastern Alai greenschist complex: Izvestiya Akademii Nauk SSSR, Seriya Geologicheskaya, v. 12, p. 19-24. [In Russian.]

1987, Tectonofacies and metamorphic features of eastern Alai greenschist complex (southern Tien Shan): Izvestiya Akademii Nauk Kazakhskoy SSR, Seriya Geologicheskaza, v. 6, p. 23-30. [In Russian.]

Yagovkin, A.V., 1974, Sedimentary and pyroclastic Paleozoic formations of the eastern Alai, in Porshnyakov, G.S., ed., Problems of stratigraphy: Leningrad, Leningrad State University Publishers, v. 1, p. 21-36. [In Russian.] $[\square$

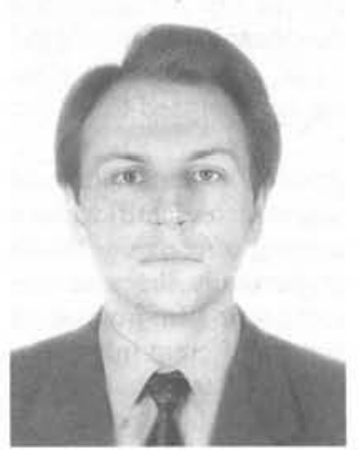

Dr. Alexis Soloviev is a research geologist with the Geological Institute of the Russian Academy of Sciences (Moscow, Pyzhevskiy, 7, GIN, Russia). His research interests focus on the geology of the southern Tien Shan metamorphic complexes, their tectonic structures and geologic settings, and the development of their geotectonic history. His special interest is the Variscan structure of greenschist complexes such as the Sugut, Kun, and Jagnob types. 